\title{
Intercontinental Networks Between Africa and Asia Across the Indian Ocean: What Do Village Chickens Reveal?
}

\author{
J.M. Mwacharo
}

\section{INTRODUCTION}

The prehistory of the Indian Ocean world can be likened to a complex historical jigsaw puzzle, and has attracted deep interest from various disciplines (Chaudhuri 1985; Pearson 2011). The objective has been to find and fit together the various pieces to complete and demystify the puzzle. At present, the assembled pieces reveal a multiplex pattern of cultural contacts, trade, and biological translocations, including intercontinental linkages and interactions that shifted according to region and over time.

I would like to extend my gratitude to the University of Nottingham and the International Centre for Agricultural Research in Dry Areas (ICARDA) for access to library and computer facilities and for giving me time to write this chapter. Special thanks go to Gwyn Campbell for his valuable comments on an earlier version of this chapter and for extending the invitation and encouraging me to put together this chapter.

J.M. Mwacharo $(\bowtie)$

University of Nottingham, Nottingham, UK; ICARDA, Addis Ababa Ethiopia

(C) The Author(s) 2016

G. Campbell (ed.), Early Exchange between Africa and the Wider

Indian Ocean World, DOI 10.1007/978-3-319-33822-4_11 
The Indian Ocean, 73.56 million $\mathrm{km}^{2}$ in area, and characterized by significant ecological and cultural diversity, witnessed some of the world's earliest seafaring and maritime activities. Evidence from archaeo-botany and archaeo-zoology reveals wild and domestic plants and animals, weeds, and spices were translocated east and westward across the Indian Ocean between diverse geographic regions (see Boivin and Fuller 2009; Boivin et al. 2009; Fuller and Boivin 2009; Fuller et al. 2011). These contacts and translocations led to major socioeconomic transformations that contributed to the evolution of languages, ideas, and technologies, including the alteration of the genetic constitution of humans, plants, and animals (Arnold 1995; Pearson 2011). These are reflected in the complexity of the different cultures, languages, and genetic traits on the present-day coastal communities of eastern Africa and Madagascar. They reflect rich and ancient long-distance linkages with the Middle East, and Asia, although mystery still surrounds the long-term evolution of such connections.

The advent of seafaring was a critical catalyst for intercontinental linkages that placed water masses at the heart of international trade routes and interactions. Through seafaring activities, many domesticates were dispersed along maritime corridors and these influenced substantially the development of agriculture. Domestic chicken were an intrinsic part of these translocations in historic times, possibly much earlier. The debate over the origin and movement of domestic village chickens is therefore an important one in understanding and reconstructing the trajectories of prehistoric human activities and relationships.

In this chapter, the current state of molecular genetic evidence based on the analysis of mtDNA datasets of village chickens is reviewed, attention being drawn to emerging scenarios for the dispersal of the species and therefore of early interaction and contacts which led to the emergence of complex trade networks that have been described in classical texts such as the Periplus Maris Erythraei (Casson 1980, 1989; Chami 1999a; Cappers 2006).

\section{Domestic Chicken as a Biological Marker to Track Human Migration and Interactions}

Domesticated animal and plant species are attractive options for unraveling patterns of human migrations. They offer a means to circumvent the sampling and analysis of rare and often scarce ancient human and animal 
remains. Some selected examples of wild and domestic animals that have been used to trace human movements and migrations are shown in Table 11.1. Chickens are a mostly sedentary species (Johnsgard 1999), have a restricted home range, and are incapable or poorly adapted to self-disperse by any means (Collias and Collias 1996; Kelly 2006). These factors together with their sociocultural and economic significance for humans imply that their current extensive dispersal and global distribution (Simoons 1994) is the result of anthropogenic dispersals. Nevertheless, a full account of their past translocations via maritime and terrestrial corridors still remains uncertain.

Table 11.1 Some selected domestic and wild animal species dispersed across the Indian Ocean

\begin{tabular}{ll}
\hline Animal species & Possible origin and distribution \\
\hline Zebu cattle (Bos indicus) & $\begin{array}{l}\text { South Asia; Widespread across eastern and southern Africa } \\
\text { (Hanotte et al. 2002) }\end{array}$ \\
Sheep (Ovis aries) & The Fertile crescent; Widespread worldwide (Chessa et al. \\
& The9) \\
Goats (Capra bircus) & 2001; Fernandez et al. 2006) \\
& South/Southeast Asia; Currently widespread in Indian Ocean \\
Asian house shrew (Suncus & (Fuller and Boivin 2009) \\
murinus) & Southeast Asia; Widespread in Madagascar, Indian ocean \\
Asian tiger mosquito & islands, across Africa, Europe, and the Americas (Vazeille \\
(Aedes albopictus) & et al. 2001; Benedict et al. 2007) \\
& South/Southeast Asia; Widespread in Indian Ocean (Fuller \\
Black/ship rat (Rattus & and Boivin 2009) \\
rattus) & Natural distribution across mainland Eurasia; Translocated to \\
House gecko & Indian Ocean islands via natural and anthropogenic means \\
(Hemidactylus) & Asia (northern India to Southwest Asia); Transferred along \\
House mouse (Mus & terrestrial and maritime routes (Fuller and Boivin 2009) \\
musculus) & South/Southeast Asia; Transferred by direct maritime route \\
Pygmy shrew (Suncus & to Madagascar (Omar et al. 2011) \\
etruscus) & Eurasia multiple times; Widespread in Indian Ocean (Walsh \\
Feral domestic pig (Sus & 2007) \\
scrofa) & South/Southeast Asia (Walsh 2007) \\
Javan Moongose & South/Southeast Asia; Widespread in Indian Ocean (Walsh \\
(Herpestes javanicus) & 2007; Larson et al. 2010) \\
Indian civet (Viverricula & indica)
\end{tabular}

Adapted and modified from Fuller and Boivin (2009). 


\section{Domestic Village Chickens in AFRiCA}

\section{Theories on Chicken Domestication, and Occurrence in Africa}

The main wild ancestor of domestic chicken, the red junglefowl Gallus gallus, occurs in sub-Himalayan northern India, southern China, and Southeast Asia (Delacour 1957; Johnsgard 1999). Whether or not the species was domesticated in a single geographic center in Southeast Asia (Niu et al. 2002; Fumihito et al. 1994, 1996) or across the geographic range of the wild species in South, East, and South-East Asia (Liu et al. 2006; Kanginakudru et al. 2008; Miao et al. 2013) remains a subject under intense debate among scholars. The issue of chicken domestication seems more complex than it appears with emerging molecular genetic evidence revealing possibilities of hybridization between all the species of the genus Gallus except Gallus varius (Nishibori et al. 2005), and the contribution of the yellow skin gene to domestic chicken by the grey junglefowl, Gallus sonneratii, which is endemic to southern India (Eriksson et al. 2008). Indeed, hybridization between wild and domestic fowls has been observed in Yunnan, China (Chang 2009), and has also been inferred in northern Vietnam (Berthouly et al. 2009).

The first skeletal remains of domestic chicken came from Chinese archaeological sites of Chishan in Hebei Province, and Peiligan in Henan Province dating to around 8000 years ago (Chow 1984; Rodwell 1984-1985). However, the validity of these bones has recently been questioned because their reanalysis has shown them to be of pheasants (Peters 1998; Deng et al. 2014). In the Indian subcontinent, evidence of the wild Gallus in Damdana, in the Ganges region, dates to between the fourth and second millennium BCE (Thomas et al. 1995 cited in Fuller 2006), while, several finds point to the presence of chicken by the mid-third millennium BCE in the western regions of Gujarat and in the Indus Valley, areas where the wild progenitor is absent today (Fuller 2006). Other finds from North India, within the home range of the wild progenitor, also date to the second half of the third millennium BCE (Fuller 2006). Very little archaeological evidence for early agriculture in mainland Southeast Asia exists (Glover and Bellwood 2004). It is not clear therefore whether chicken domestication occurred independently in this region. Thailand has been proposed as a center of chicken domestication (Fumihito et al. 1994, 1996). The earliest G. gallus remains identified in Thailand archaeological sites date to approximately 4000 years ago (Higham 1989). The 
cultural importance of chickens in Thailand is demonstrated by the interment of chickens alongside humans in the archaeological sites of Non Nok Tha and Ban Na Di (Higham 1989). Preserved chicken remains from archaeological sites in Island Southeast Asia are scarce and their utilization by ancient humans is often inferred based on their depiction on pottery or in paintings than by the occurrence of their remains in archaeological sites (Bellwood 2007).

The significance of domestic chicken in the sociocultural life and subsistence economy of most African societies (MacDonald 1992, 1995a) has been interpreted to suggest one of three possibilities: a long-term presence on the continent; a late arrival and quick integration into local customs and traditions (MacDonald 1995a,b), or multiple introductions at different time periods to fulfill multiple functions. However, no archaeological data has so far been found to support any of these suggestions (Williamson 2000).

Linguistic evidence, on the other hand, supports an early introduction and complex history of arrival and dispersal across Africa. Working on the basis of the distribution pattern of the root word for fowl across three African language groups, Williamson (2000) suggested at least two separate introductions and three routes of dispersal into West Africa-two across Central Africa and the Sudano-Sahelian zone from the east coast of Africa and one from North Africa across the Sahara. Further, noting that the terminologies relating to domestic animals in Madagascar appear to have been derived from the Swahili language, Blench (2008) suggested that the domestic chicken found in the island could have been introduced from the Comoros islands or East Africa.

Archeological evidence for the arrival of the chicken in, and its dispersal across, Africa remains scant and, in some cases, disputed. The picture is further complicated by the challenging task of identifying domestic chicken bones from those of indigenous African galliform's (MacDonald 1992). The few remains that have been identified show that, at the earliest, the domestic chicken was present in Egypt around the second millennium BCE (Houlihan and Goodman 1986). Until recently, the oldest, securely identified chicken remains in West Africa were from Jenne-Jeno, in modern-day Mali, dated to 500-850 CE (MacDonald 1995b) although this is contested as it has been suggested that these finds most likely date to the eighth or ninth century CE (Dueppen 2011). New evidence from Kirikongo, in Burkina Faso, indicates that the chicken was common in West Africa by the sixth century CE, where it was probably 
present as early as the first century CE (Dueppen 2011). Research in East Africa shows that the chicken was common in several sites by the eighth to ninth centuries CE (Horton and Mudida 1996; Wilson and Omar 1997; Boivin et al. 2013). The earliest undisputed findings are from Unguja Ukuu, in Zanzibar Island dating to the sixth to mid-eighth century CE (Juma 2004). In southern Africa, evidence points to the occurrence of the chicken around the eighth to ninth century CE (see review by Mwacharo et al. 2013).

On the basis of the geographic distribution and dating of the purportedly most ancient undisputed zoo-archeological (c. 1567-1320 BCE) findings, as well as artistic (c. 1425-1123 BCE) and literary (1504-1450 $\mathrm{BCE}$ ) evidence, it is currently considered that the chicken may have initially entered Africa through Egypt, dispersed southwards along the Nile Valley to Nubia, where archeological evidence dates the presence of chicken to the late fifth century CE (Houlihan and Goodman 1986), and subsequently reached West Africa through the Sudano-Sahelian corridor (MacDonald and Edwards 1993; Fuller et al. 2011). MacDonald and Edwards (1993) further suggested an independent diffusion into West Africa through the Sudano-Sahelian belt from the east African coast. This was perhaps related to the Indian Ocean trading networks. Boivin et al. (2013) point to the common simultaneous occurrence of remains of the common rat, Rattus rattus (a ship borne introduction), and the chicken in several sites on the coast and islands of eastern Africa, as well as in southern Africa, dating from the mid to late first millennium CE. This suggests an influx of the two species due to intensifying Indian Ocean trade.

\section{Genetic Evidence Based on the Analysis of mtDNA Sequences}

In the past two or so decades, researchers have analyzed mitochondrial DNA (mtDNA) as a standard way of reconstructing dispersal routes and dispersal chronology of domestic animals in different geographic regions (Bruford et al. 2003). Such reconstructions have been achieved by assessing phylogenetic relationships of haplotypes and Clades for various wild and domestic species. Some of these species include rats (Matisoo-Smith and Robins 2004), sheep (Chessa et al. 2009), goats (Fernandez et al. 2006), cattle (Edwards et al. 2007), pigs (Larson et al. 2010), and the chicken (Storey et al. 2012). Three factors render mtDNA attractive in this respect. First, its occurrence in high copy number in the mitochondria of most eukaryotic cells makes it appropriate for studying modern and 
ancient samples (Clayton 1991). Second, its almost complete maternal inheritance and rare recombination (Ho and Gilbert 2010; Pakendorf and Stoneking 2005), makes it appropriate to trace the maternal lineage of species. Third, its high mutation rate and polymorphism, especially of the control (D-loop) region, (Pakendorf and Stoneking 2005), makes it the fragment of choice for within-species comparisons.

Nine mtDNA clades (A, B, C, D, E, F, G, H, I) have been defined from an analysis of the first 539 base pairs of the control region of domestic chickens from Europe and Asia as well as wild red jungle fowl (Liu et al. 2006; Miao et al. 2013). Seven clades (A-G) had sequences from both domestic and wild chickens. In this chapter, the nomenclature of the mtDNA clades observed in domestic chicken follows that of Liu et al. (2006). A few studies have analyzed a similar fragment in village chickens from countries around the Indian Ocean (Fig. 11.1; Tables 11.2 and 11.3). These include from Africa (Razafindraibe et al. 2008; Adebambo et al. 2010; Muchadeyi et al. 2008; Mtileni et al. 2011; Mwacharo et al. 2011; Lyimo et al. 2013; Wani et al. 2014; Elkhaiat et al. 2014; Al-Qamashoui 2014), the Middle East (Liu et al. 2006), the Arabian Peninsula

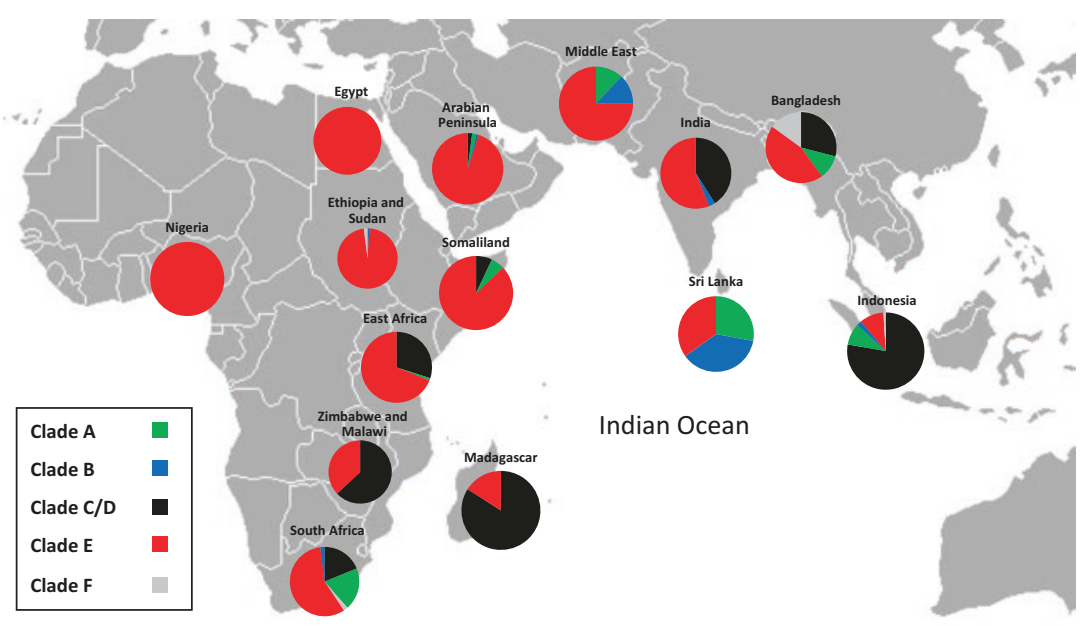

Fig. 11.1 Pie charts showing the proportion of the different mtDNA clades observed in domestic village chickens from countries/regions bordering the Indian Ocean. 


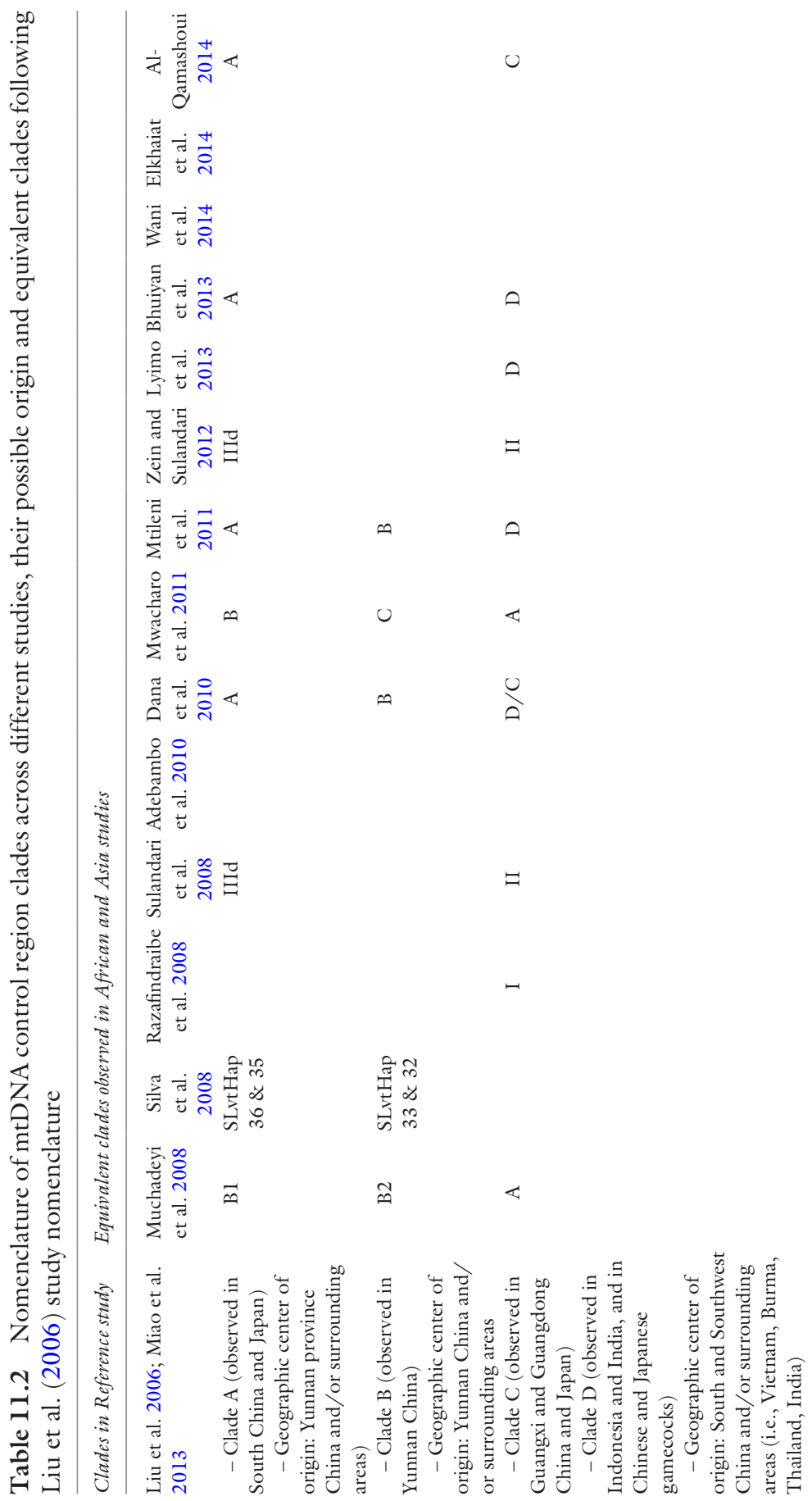




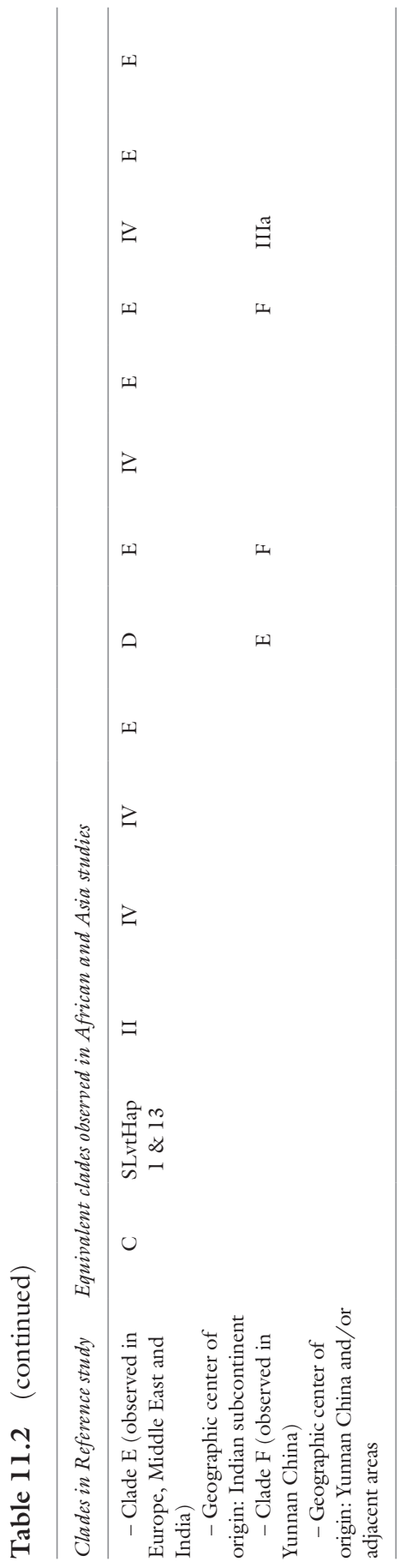


Table 11.3 Clades observed from the analysis of mtDNA D-loop sequences of village chickens from countries around the Indian Ocean

\begin{tabular}{|c|c|c|c|c|c|c|c|}
\hline \multirow[t]{2}{*}{ Region/country/study } & \multirow[t]{2}{*}{ Countries } & \multirow{2}{*}{$\begin{array}{l}\text { Sample } \\
\text { size }\end{array}$} & \multicolumn{5}{|c|}{ Frequency of clades (\%) } \\
\hline & & & $C / D$ & $A$ & $B$ & $E$ & $F$ \\
\hline \multicolumn{8}{|l|}{ Madagascar } \\
\hline Razafindraibe et al. (2008) & Madagascar & 77 & 84 & & & 16 & \\
\hline \multicolumn{8}{|l|}{ South Africa } \\
\hline Mtileni et al. (2011) & South Africa & 111 & 19 & 20 & 2 & 57 & 2 \\
\hline \multicolumn{8}{|l|}{ South-East Africa } \\
\hline \multirow{2}{*}{ Muchadeyi et al. (2008) } & Zimbabwe & 99 & 55 & & & 45 & \\
\hline & Malawi & 19 & 100 & & & & \\
\hline \multicolumn{8}{|l|}{ East Africa } \\
\hline \multirow[t]{2}{*}{ Mwacharo et al. (2011) } & Kenya & 211 & 45 & $<1$ & & 54 & \\
\hline & Uganda & 123 & & & & 100 & \\
\hline Lyimo et al. (2013) & Tanzania & 101 & 36 & & & 64 & \\
\hline \multicolumn{8}{|l|}{ Ethiopia and Sudan } \\
\hline Muchadeyi et al. (2008) & Sudan & 20 & & & & 100 & \\
\hline \multirow{2}{*}{ Mwacharo et al. (2011) } & Sudan & 135 & & & & 98 & 2 \\
\hline & Ethiopia & 42 & & & 2 & 96 & 2 \\
\hline Wani et al. (2014) & Sudan & 81 & & & & 99 & 1 \\
\hline \multicolumn{8}{|l|}{ West Africa } \\
\hline Adebambo et al. (2010) & Nigeria & 232 & & & & 100 & \\
\hline \multicolumn{8}{|l|}{ North-East Africa } \\
\hline Elkhaiat et al. (2014) & Egypt & 36 & & & & 100 & \\
\hline Al-Qamashoui (2014) & Somaliland & 15 & 7 & 6 & & 87 & \\
\hline \multicolumn{8}{|c|}{ The Middle East and Arabian Peninsula } \\
\hline \multirow[t]{3}{*}{ Al-Qamashoui (2014) } & Oman & 100 & 2 & 4 & & 94 & \\
\hline & Saudi Arabia & 61 & & & 2 & 98 & \\
\hline & Yemen & 31 & 4 & & 3 & 93 & \\
\hline Liu et al. (2006) & Middle East ${ }^{\mathrm{b}}$ & 16 & & 12 & 13 & 75 & \\
\hline \multicolumn{8}{|l|}{ Indian subcontinent } \\
\hline Bhuiyan et al. (2013) & Bangladesh & 85 & 29 & 11 & & 45 & 15 \\
\hline Liu et al. (2006) & India & 27 & 41 & & 3 & 56 & \\
\hline Silva et al. (2008) & Sri Lanka & 132 & & 12 & 16 & 15 & \\
\hline \multicolumn{8}{|l|}{ Southeast Asia } \\
\hline Liu et al. (2006) & Indonesia & 12 & 42 & & 25 & 33 & \\
\hline Zein and Sulandari (2012) & Indonesia & 210 & 84 & 4 & 2 & 8 & \\
\hline Sulandari et al. (2008) & Indonesia & 483 & 75 & 11 & 1 & 11 & 2 \\
\hline \multicolumn{8}{|l|}{ Across Eurasia } \\
\hline Liu et al. $(2006)^{c}$ & $\begin{array}{l}\text { Europe and } \\
\text { Asia }\end{array}$ & 836 & $10 / 5$ & 27 & 23 & 19 & 8 \\
\hline
\end{tabular}

${ }^{a}$ Nomenclature follows that of Liu et al. (2006) study.

'Iran, Turkmenistan, Azerbaijan

'Liu et al. also observed clades $\mathrm{G}$ and I which are not present in domestic chicken from Africa, the Indian Subcontinent, Island Southeast Asia, the Middle East, and Arabian Peninsula 
(Al-Qamashoui 2014), Sri Lanka (Silva et al. 2008), India (Liu et al. 2006), Bangladesh (Bhuiyan et al. 2013), and Indonesia (Liu et al. 2006; Zein and Sulandari 2012; Sulandari et al. 2008) (see Tables 11.2 and 11.3). Of the seven mtDNA clades observed in domestic and wild chickens (Liu et al. 2006), at least two are found in countries bordering the Indian Ocean (see Fig. 11.1; Table 11.3). The most common are clades $\mathrm{C} / \mathrm{D}$ and $\mathrm{E}$, while $\mathrm{A}, \mathrm{B}$, and $\mathrm{F}$ are rare (Fig. 11.1; Table 11.3). This suggests the presence of significant genetic diversity and possibilities of multiple origins and introductions.

Clade $\mathrm{E}$ is the most diverse and is widely distributed across the countries studied so far bordering the Indian Ocean (Fig. 11.1; Table 11.3). The next most common is clade $\mathrm{C} / \mathrm{D}$. In Africa, it occurs in countries adjacent to the Indian Ocean. It has so far not been observed in the continents hinterland (Fig. 11.1; Table 11.3). Outside Africa, the clade is predominant in Indonesia and occurs, albeit at low frequencies compared to clade E, in Bangladesh, India and in the Arabian Peninsula. It has not so far been observed in the Middle East and in Sri Lanka (Table 11.3). Clades A, B, and F occur in only four countries in Africa and at very low frequencies (Table 11.3). Clade A has been observed in Kenya, South Africa, and Somaliland; clade B in Ethiopia and South Africa and clade F in Ethiopia, Sudan, and South Africa (Table 11.3). Outside the African continent, clade A is present in Bangladesh and Sri Lanka, in Indonesia, in the Arabian Peninsula (Oman) and in the Middle East (Table 11.3). Clade B is present in India, Sri Lanka, Indonesia, the Arabian Peninsula and in the Middle East while clade F occurs in Bangladesh and Indonesia (Table 11.3).

\section{Origin and Dispersal of the Five Clades}

It has been suggested that clade $\mathrm{C} / \mathrm{D}$ originates from Southeast Asia (Muchadeyi et al. 2008; Mwacharo et al. 2011; Miao et al. 2013). Liu et al. (2006) on the other hand, suggested an origin in South and Southwest China and/or surrounding areas, that is, Vietnam, Thailand, and Burma. The clade has a very large presence in the Indonesian islands (Fig. 11.1; Table 11.3). From its geographic distribution pattern, it has been argued that this clade reached East Africa (Mwacharo et al. 2011) including Madagascar (Razafindraibe et al. 2008) via a maritime corridor (Mwacharo et al. 2011). Based on the known history of human colonization of Madagascar (Razafindrazaka et al. 2010 and references therein; 
Blench 2010), Razafindraibe et al. (2008) have suggested the origin of the clade to be the Indonesian islands; and that it is likely the legacy of Austronesian expansion to eastern Africa and Madagascar (Razafindraibe et al. 2008). Based on the decrease in diversity and frequency of this clade northwards from Madagascar along the Indian Ocean, Al-Qamashoui (2014) suggested it could have been introduced to East Africa and the Arabian Peninsula from Madagascar following its direct arrival in the island from either China or Indonesia. Another possibility is an introduction to the Arabian Peninsula, then to the Horn of Africa and East and southern Africa from India where the clade is also observed (Fig. 11.1; Table 11.3) across the Arabian Sea.

Given the available data, it is difficult to determine if this clade (C/D) arrived first in East Africa or Madagascar, or simultaneously along the eastern and southern Africa coastline including Madagascar. Several hypotheses offer themselves. One is that the clade traveled directly to East Africa, from where it was then introduced to Madagascar, and down the east African coast to southern Africa. A second is that it traveled first to Madagascar, and subsequently to East and southern Africa. The third possibility is that it was introduced simultaneously to Madagascar, eastern and southern Africa. Within Asia, the clade may have been introduced to Bangladesh and India from Indonesia across the Bay of Bengal. However, if it is assumed that the clade originates from South and Southwest China and adjacent regions as suggested by Liu et al. (2006), then an overland introduction will be the most likely. More data will be required before any of these hypotheses can be confirmed.

Liu et al. (2006) and Miao et al. (2013) proposed the geographic center of origin of clade E to be the Indian subcontinent (Table 11.2). This proposition gained the support of Muchadeyi et al. (2008) and Mwacharo et al. (2011). It is further backed by the commonly observed yellow skin phenotype among African (Daikwo et al. 2011; Melesse and Negesse 2011; El-Safty 2012) and Saudi Arabian (personal observation by the author) village chickens; a marker of introgression of the yellow skin gene (BCO2) into domestic fowls from the grey junglefowl of southern India (Eriksson et al. 2008). Whether or not this clade followed a maritime and/or terrestrial corridor to reach Africa and the Arabian Peninsula remains debatable. What may be certain however is that it was introduced to the Middle East via terrestrial dispersal. Given its occurrence in the Middle East, the Arabian Peninsula, Northeast, 
West, eastern and southern Africa (Fig. 11.1; Table 11.3), three possible routes of dispersal are envisaged. One is an overland dispersal from the Indian subcontinent via the Middle East to the Arabian Peninsula and Northeast Africa (Egypt). It then traveled south, along the Nile Valley, then westwards across the Sudano-Sahelian zone into West Africa. A direct maritime introduction via the Arabian Sea into the Arabian Peninsula and the Horn of Africa (Somaliland, Djibouti, etc.) is also possible and is favored by Al-Qamashoui (2014). Another possibility is that the clade reached East Africa and Madagascar directly overseas from the Indian subcontinent, or from Egypt traveling along the Red Sea and east African coasts. This suggestion has also been proposed by Al-Qamashoui (2014) based on the observation of a southward decline in the frequency and diversity of the clade from the Arabian Peninsula to southern Africa (see Fig. 11.1). A terrestrial dispersal accompanying the expansion of Bantu-speakers into southern Africa from the Great Lakes region cannot be discounted. It is the only clade observed in West Africa (Adebambo et al. 2010), the original homeland of the Bantu-speakers, and in the interlacustrine region of East Africa (Mwacharo et al. 2011), where the first Bantu-speaking migrants arrived around 1000 BCE (Russell et al. 2014 and references therein). In Asia, the clade may have been introduced to Sri Lanka and Indonesia by traveling across the Bay of Bengal.

Liu et al. (2006) proposed the center(s) of origin of clade(s) A and B (Tables 11.2 and 11.3) as Yunnan Province in China and/or surrounding areas. The presence of identical or closely related haplotypes of these two clades in European local chickens and fancy breeds and commercial breeds of chicken (Muchadeyi et al. 2008; Dana et al. 2010; Miao et al. 2013), led Mwacharo et al. (2011) to propose that they were introduced to Africa following the introduction of exotic and/or commercial breeds (broilers and layers) for crossbreeding purposes with local flocks to increase egg and meat production. The same can be used to explain the occurrence of these two clades in the Arabian Peninsula, the Middle East, the Indian subcontinent, and Indonesia (Fig. 11.1; Table 11.3). However, an earlier introduction to Africa from China via Sri Lanka, is also likely, as is, the possibility of overland introductions from Yunnan province to the Indian subcontinent and subsequently, to the Middle East and Arabian Peninsula. More data are required to further clarify and/or confirm the origin(s) and mode of dispersal of these two clades. 
Clade F (Tables 11.2 and 11.3) has not been observed in commercial broilers and layers (Muchadeyi et al. 2008; Dana et al. 2010) and in European local chickens (Liu et al. 2006; Miao et al. 2013). Liu et al. (2006) have proposed the center of origin of the clade as South China (Yunnan province) and/or adjacent geographic regions such as Myanmar. The route(s) of introduction of the clade to Africa, Bangladesh, and Indonesia remains unknown. Its modern-day worldwide geographic distribution (Liu et al. 2006) hints to the possibility that it was most likely the consequence of either direct or indirect maritime introduction via Sri Lanka from Yunnan province. Its arrival in East Africa might have been facilitated by either the fifteenth century Chinese maritime trading or exploration activities across the Indian Ocean (Duyvendak 1939; Beaujard 2005; Mwacharo et al. 2011), and/or it traveled as a companion haplotype to other clades such as clade A. While its dispersal to Indonesia could have been through the Bay of Bengal, its dispersal to Bangladesh was most likely via a terrestrial route.

\section{Conclusions and Future Directions}

The Indian Ocean was a major arena for the exchange of flora and fauna from early times (Boivin et al. 2013; Fuller et al. 2011). Chickens were among the fauna that were transported from Asia to Africa, but there is still considerable debate as to their origins and dispersal patterns. The five mtDNA clades found in village chickens around the Indian Ocean rim, and the dating of zoo-archeological remains, highlight the important role in this exchange played by Africa's eastern and southern coastlines including Madagascar, the Indian subcontinent, and Southeast Asia. In this chapter, I attempt to outline what the discipline of molecular genetics, through an analysis of chicken mtDNA, further reveals about the issue. It is important to emphasize that the emerging picture from the analysis of such data is far from complete. Too few sites on the littorals of Africa and Asia bordering the Indian Ocean have been sampled and studied in detail, and the proposed tentative hypotheses offered here concerning the routes of dispersal need to be tested. Studies to date nonetheless offer some interesting preliminary observations, notably multiple origins and introductions for village chickens, and genetic contributions from South Asia, East Asia, and Southeast Asia. This highlights the complexity of the trans-Indian Ocean world interaction from early times. 


\section{REFERENCES}

Adebambo, A.O., et al. 2010. Lack of Phylogeographic Structure in Nigerian Village Chicken Revealed by Mitochondrial DNA D-loop Sequence Analysis. International Journal of Poultry Science. 9(5): 503-507.

Al-Qamashoui, B. 2014. Towards Conservation of Omani Local Chicken: Management, Performance and Genetic Diversity. PhD Thesis, Georg-AugustUniversitat, Gottingen. Gottingen, Germany: Cuvillier Verlag, 70pp.

Arnold, J.E. 1995. Transportation Innovation and Social Complexity Among Maritime Hunter-Gatherer Communities. American Anthropologist. 97(4): 733-747.

Beaujard, P. 2005. The Indian Ocean in Eurasia and African World-Systems before the Sixteenth Century. Journal of World History 16(4): 411-465.

Bellwood, P. 2007. Prehistory of the Indo-Malaysian Archipelago. Honolulu: University of Hawaii Press.

Benedict, M.Q., et al. 2007. Spread of the Tiger: Global Risk of Invasion by the Mosquito Aedes Albopictus. Vector-Borne and Zoonotic Diseases 7(1): 76-85.

Berthouly, C., et al. 2009. Genetic Analysis of Local Vietnamese Chickens Provides Evidence of Gene Flow from Wild to Domestic Populations. BMC Genetics. 10 : 1. doi:10.1186/1471-2156-10-1.

Bhuiyan, M.S.A., et al. 2013. Genetic Diversity and Maternal Origin of Bangladesh Chicken. Molecular Biology Reproduction 40(6): 4123-4128.

Blench, Roger. 2008. The Austronesians in Madagascar and Their Interaction with the Bantu of the East African Coast: Surveying the Linguistic Evidence for Domestic and Translocated Animals. Studies in Philippine Languages and Cultures 18: 18-43.

Blench, Roger. 2010. Evidence for the Austronesian Voyages in the Indian Ocean. In The Global Origins and Development of Seafaring, ed. A. Anderson, et al., 239-248. Cambridge, UK: McDonald Institute for Arcaeological Research, University of Cambridge.

Boivin, N., and D.Q. Fuller. 2009. Shell Middens, Ships and Seeds: Exploring Coastal Subsistence, Maritime Trade and the Dispersal of Domesticates in and Around the Ancient Arabian Peninsula. Journal of World Prehistory 22(2): 113-180.

Boivin, N., R. Blench, and D.Q. Fuller. 2009. Archaeological, Linguistic and Historical Sources on Ancient Seafaring: A Multidisciplinary Approach to the Study of Early Maritime Contact and Exchange in the Arabian Peninsula. In The Evolution of Human Populations in Arabia. Paleoenvironments, Prehistory and Genetics, ed. D. Petraglia and J.I. Rose, 251-278. Dordrecht: Springer.

Boivin, N., et al. 2013. East Africa and Madagascar in the Indian Ocean World. Journal of World Prehistory 26(3): 213-281.

Bruford, M.W., D.G. Bradley, and G. Luikart. 2003. DNA Markers Reveal the Complexity of Livestock Domestication. Nature Reviews Genetics 4(11): 900-910. 
Cappers, R. 2006. Roman Foodprints at Berenike: Archaeobotanical Evidence of Subsistence and Trade in the Eastern Desert of Egypt. Los Angeles, CA: Costen Institute of Archaeology.

Casson, L. 1980. Rome's Trade with the East: The Sea Voyage to Africa and India. Transactions of the American Philological Association 110: 21-36.

- 1989. The Periplus Maris Erythraei: Text with Introduction, Translation, and Commentary. Princeton, NJ: Princeton University Press [Reprint 2012].

Chami, F. 1999a. Graeco-Roman Trade Link and the Bantu Migration Theory. Anthropos 94(1-3): 205-215.

Chang, H. 2009. Animal Genetic Resources. Beijing: Science Press of China [in Chinese].

Chaudhuri, K.N. 1985. Trade and Civilisation in the Indian Ocean. An Economic History from the Rise of Islam to 1750. Cambridge: Cambridge University Press.

Chessa, B., et al. 2009. Revealing the History of Sheep Domestication Using Retrovirus Integrations. Science 324(5926): 532-536.

Chow, B-S. 1984. Animal Domestication in Neolithic China. In Animals and Archaeology: 3. Early Herders and Their Flocks, ed. J. Clutton-Brock and J. Grigson, 363-369. British Oxford: B.A.R.

Clayton, D.A. 1991. Replication and Transcription of Vertebrate Mitochondrial DNA. Annual Review of Cell Biology 7: 453-478.

Collias, N.E., and E.C. Collias. 1996. Social Organization of a Red Junglefowl, Gallus gallus, Population Related to Evolution Theory. Animal Behaviour $51(6)$ : 1337-1354.

Daikwo, I.S., A.A. Okpe, and J.O. Ocheja. 2011. Phenotypic Characterization of Local Chickens in Dekina. International Journal of Poultry Science 10(6): 444-447.

Dana, N., et al. 2010. East Asian Contributions to Dutch Traditional and Western Commercial Chickens Inferred from mtDNA Analysis. Animal Genetics 42(2): $125-133$.

Delacour, J. 1957. The Pheasants of the World. Surrey/Hindhead: Spue Publications.

Deng, H., et al. 2014. The Re-examination of the Domestic Chicken in Ancient China. Chinese Archaeology 14(1): 189-193.

Dueppen, S.A. 2011. Early Evidence for Chicken at Iron Age Kirikongo (c AD 100-1450), Burkina Faso. Antiquity 85(327): 142-157.

Duyvendak, J.J.L. 1939. The True Dates of the Chinese Maritime Expeditions in the Early Fifteenth Century. T'oung Pao 34(5): 341-413.

Edwards, C.J., et al. 2007. Mitochondrial DNA Analysis Shows a Near Eastern Neolithic Origin for Domestic Cattle and No Indication of Domestication of European Aurochs. Proceedings of the Royal Society B: Biological Sciences 274(1616): 1377-1385.

Elkhaiat, I., et al. 2014. Genetic Diversity of Egyptian Native Chickens Using mtDNA D-loop Region. Journal of Poultry Science 51(4). doi:10.2141/ jpsa0130232. 
El-Safty, S.A. 2012. Determination of Some Quantitative and Qualitative Traits in Libyan Native Fowls. Egypt Poultry Science 32(2): 247-258.

Eriksson, J., et al. 2008. Identification of the Yellow Skin Gene Reveals a Hybrid Origin of the Domestic Chicken. PLoS Genetics 4(2): e1000010.

Fernandez, H., et al. 2006. Divergent mtDNA Lineages of Goats in an Early Neolithic Site, Far from the Initial Domestication Areas. Proceedings of the National Academy of Sciences of the United States of America 103(42): $15375-15379$.

Fuller, D.Q. 2006. Agricultural Origins and Frontiers in South Asia: A Working Synthesis. Journal of World Prehistory 20(1): 1-86.

Fuller, D.Q., and N.L. Boivin. 2009. Crops, Cattle and Commensals across the Indian Ocean: Current and Potential Archaeobiological Evidence. Études Océan Indien 42-43: 13-46.

Fuller, D.Q., et al. 2011. Across the Indian Ocean: The Prehistoric Movement of Plants and Animals. Antiquity 85(328): 544-558.

Fumihito, A., et al. 1994. One Subspecies of the Red junglefowl (Gallus gallus gallus) Suffices as the Matriarchic Ancestor of all Domestic Breeds. Proceedings of the National Academy of Sciences of the United States of America 91(26): 12505-12509.

-1996. Monophyletic Origin and Unique Dispersal Patterns of Domestic Fowls. Proceedings of the National Academy of Sciences of the United States of America 93(13): 6792-6795.

Glover, I.C., and P.S. Bellwood. 2004. Southeast Asia: From Prehistory to History. New York: Routledge Curzon.

Hanotte, O., et al. 2002. African Pastoralism: Genetic Imprints of Origins and Migrations. Science 296(5566): 336-339.

Higham, C. 1989. The Archaeology of Mainland Southeast Asia: From 10000 B.C. to the Fall of Angkor. Cambridge: Cambridge University Press.

Ho, S.Y.W., and M.T.P. Gilbert. 2010. Ancient Mitogenomics. Mitochondrion 10(1): 1-11.

Horton, M., and N. Mudida. 1996. Subsistence at Shanga: The faunal record. In Zanzibar and Pemba: Archaeological Investigations of an Indian Ocean Archipelago, ed. M. Horton. London: British Institute in Eastern Africa.

Houlihan, P.F., and S.M. Goodman. 1986. The Birds of Ancient Egypt. Warminster: Aris and Phillips Ltd..

Johnsgard, P.A. 1999. The Pheasants of the World: Biology and Natural History. Washington, DC: Smithsonian Institution Press.

Juma, A.M. 2004. Unguja Ukun on Zanzibar: An Archaeological Study of Early Urbanism. Uppsala: Department of Archaeology and Ancient History, Uppsala University.

Kanginakudru, S. et al. 2008. Genetic Evidence From Indian Red Jungle Fowl Corroborates Multiple Domestication of Modern Day Chicken. BMC Evolutionary Biology 8:174. doi:10.1186/1471-2148-8-174. 
Kelly, L. 2006. The Little Chicken Book. Caledon, Ontario: Blue Barn Publishing.

Larson, G., et al. 2010. Patterns of East Asian Pig Domestication, Migration, and Turnover Revealed by Modern and Ancient DNA. Proceedings of the National Academy of Sciences 107(17): 7686-7691.

Liu, Y.P., et al. 2006. Multiple Maternal Origins of Chickens: Out of the Asian Jungles. Molecular Phylogenetics and Evolution 38(1): 12-19.

Liukart, G., et al. 2001. Multiple Maternal Origins and Weak Phylogeographic Structure in Domestic Goats. Proceedings of the National Academy of Sciences 98(10): 5927-5932.

Lyimo, C.M., et al. 2013. Assessing the Genetic Diversity of Five Tanzanian Chicken Ecotypes Using Molecular tools. South African Journal of Animal Science 43(4): 499-510.

MacDonald, K.C. 1992. The Domestic Chicken (Gallus gallus) in Sub-Saharan Africa: A Background to its Introduction and its Osteological Differentiation from Indigenous Fowls (Numidinae and Francolinus sp). Journal of Archaeological Science 19(3): 303-318.

- 1995a. Why Chicken? The Centrality of the Domestic Fowl in West African Ritual and Magic. In The Symbolic Role of Animals in Archaeology, ed. K. Ryan and P.J. Crabtree. Philadelphia: MASCA.

- 1995b. The Faunal Remains (Mammals, Birds and Reptiles). In Excavations at Jenne-Jeno, Hambarketolo and Kaniana (Inland Niger Delta, Mali), ed. S.K. McIntosh, 291-318. Berkeley, CA: University of California Press.

MacDonald, K.C., and D.N. Edwards. 1993. Chicken in Africa: The Importance of Qasr Ibrim. Antiquity 67(256): 584-590.

Matisoo-Smith, E., and J.H. Robins. 2004. Origins and Dispersals of Pacific Peoples: Evidence from mtDNA Phylogenies of the Pacific Rat. Proceedings of the National Academy of Sciences 101: 9167-9172.

Melesse, A., and T. Negesse. 2011. Phenotypic and Morphological Characterization of Indigenous Chicken Populations in Southern Region of Ethiopia. Animal Genetic Resources 49: 19-31.

Miao, Y.-W., et al. 2013. Chicken Domestication: An Updated Perspective Based on Mitochondrial Genomes. Heredity 110(3): 277-282.

Mtileni, B.J., et al. 2011. Diversity and Origins of South African Chickens. Poultry Science 90: 2189-2194.

Muchadeyi, F.C., et al. 2008. Mitochondrial DNA D-loop Sequences Suggest a Southeast Asian and Indian Origin of Zimbabwean Village Chicken. Animal Genetics 39(6): 615-622.

Mwacharo, J.M., et al. 2011. Mitochondrial DNA Reveals Multiple Introductions of Domestic Chicken in East Africa. Molecular Phylogenetics and Evolution 58(2): 374-382.

. 2013. The History of African Village Chickens: An Archaeological and Molecular Perspective. African Archeological Review 30(1): 97-114. 
Nishibori, M., et al. 2005. Molecular Evidence for Hybridization of Species in the Genus Gallus Except for Gallus Varius. Animal Genetics 36(5): 367-375.

Niu, D., et al. 2002. The Origin and Genetic Diversity of Chinese Indigenous Chicken Breeds. Biochemical Genetics 40(5-6): 163-174.

Omar, H., et al. 2011. Phylogenetic Relationships of Malayan and Malagasy Pygmy Shrews of the Genus Suncus (Soricomorpha: Soricidae) Inferred from Mitochondrial Cytochrome b Gene Sequences. The Raffles Bulletin of Zoology 59(2): 237-243.

Pakendorf, B., and M. Stoneking. 2005. Mitochondrial DNA and Human Evolution. Annual Review of Genomics and Human Genetics 6: 165-183.

Pearson, M. 2011. Islamic Trade, Shipping, Port-States and Merchant Communities in the Indian Ocean, Seventh to Sixteenth Centuries. In The New Cambridge History of Islam, Volume 3: The Eastern Islamic World Eleventh to Eighteenth Centuries, ed. D.O. Morgan and A. Reid, 317-365. Cambridge: Cambridge University Press.

Peters, J. 1998. Römische Tierhaltung und Tierzucht. Eine Synthese aus archäozoologischer Untersuchung und schriftlich-bildlicher Überlieferung. Rahden: Verlag Marie Leidorf.

Razafindraibe, H., et al. 2008. Mitochondrial DNA origin of Indigenous Malagasy Chicken: Implications for a Functional Polymorphisim at the Mx Gene. Annals of the New York Academy of Sciences 1149: 77-79.

Razafindrazaka, H., et al. 2010. Complete Mitochondrial DNA Sequences Provide New Insights into the Polynesian Motif and the Peopling of Madagascar. European Journal of Human Genetics 18(5): 575-581.

Rodwell, S. 1984-1985. The Common Fowl in Early China. Journal of the Hong Kong Archaeological Society 11: 124-127.

Russell, T., F. Silva, and J. Steele. 2014. Modelling the Spread of Farming in the Bantu-Speaking Regions of Africa: An Archaeology-Based Phylogeography. PLoS ONE 9: e87854. doi:10.1371/journal.pone.0087854.

Silva, P., et al. 2008. Mitochondrial DNA Based Analysis of Genetic Variation and Relatedness among Sri Lankan Indigenous Chickens and the Ceylon Junglefowl (Gallus lafayetti). Animal Genetics. 40(1): 1-9.

Simoons, F.J. 1994. Eat Not this Flesh: Food Avoidances from Prehistory to the Present. Madison: University of Wisconsin Press.

Storey, A.A., et al. 2012. Investigating the Global Dispersal of Chickens in Prehistory Using Ancient Mitochondrial DNA Signatures. PLoS ONE 7(7): e39171.

Sulandari, S., M.A. Zein, and T. Sartika. 2008. Molecular Characterization of Indonesian Indigenous Chickens Based on Mitochondrial DNA Displacement (D)-loop Sequences. HAYATI Journal of Biosciences 15(4): 145-154.

Vazeille, M., et al. 2001. Population Genetic Structure and Competence as a Vector for Dengue Type 2 Virus of Aedes aegypti and Aedes albopictus from Madagascar. American Journal of Tropical Medicine and Hygiene 65(5): 491-497. 
Walsh, M.T. 2007. Island Subsistence: Hunting, Trapping and the Translocation of Wildlife in the Western Indian Ocean. Azania 42(1): 83-113.

Wani, C.E., et al. 2014. Molecular Characterization of Sudanese and Southern Sudanese Chicken Breeds Using mtDNA D-loop. Genetics Research International. doi:10.1155/2014/928420.

Williamson, K. 2000. Did Chicken Go West? In The Origins and Development of African Livestock: Archaeology, Genetics, Linguistics and Ethnography, ed. R.M. Blench and K.C. MacDonald. London: UCL Press, Taylor and Francis Group.

Wilson, T.H., and A.L. Omar. 1997. Archaeological Investigations at Pate. Azania 32(1): 31-76.

Zein, M.S.A., and S. Sulandari. 2012. Genetic Diversity and Haplogroups Distributions of Kampung Chickens Using Hypervariable-I Mitochondrial DNA Control Region. Indonesian Journal of Animal and Veterinary Sciences 17(2): 120-131. 